HARVARD UNIVERSITY.

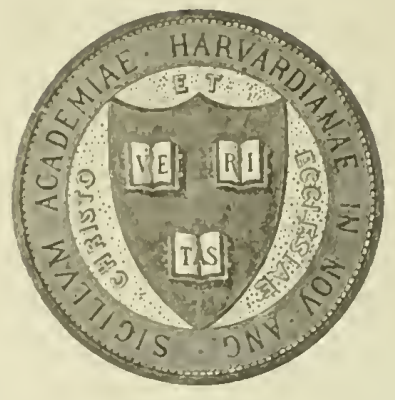

\section{LIBRARY}

OF THE

MUSEUM OF COMPARATIVE ZOÖLOGY

$$
\text { Exchange. }
$$

Cpril 22, 1918 


\title{
THE PLACE OF SHEEP ON NEW ENGLAND FARMS
}

\author{
F. H. BRANCH
}

Assistant Agriculturist

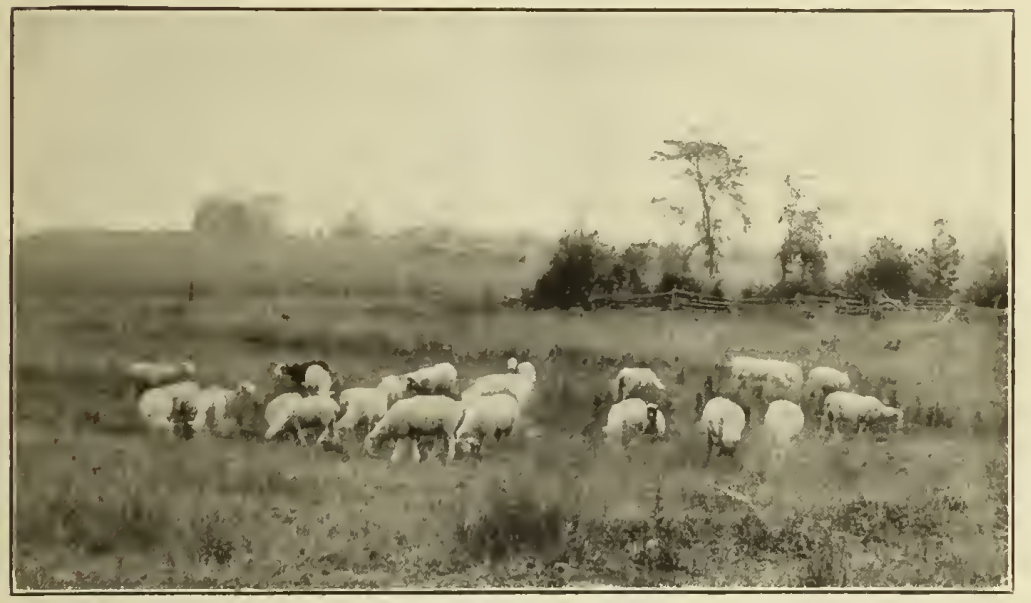

FARMERS' BULLETIN 929

UNITED STATES DEPARTMENT OF AGRICULTURE

OFFICE OF THE SECRETARY

Contribution from the Office of Farm Management

w. J. SPILLMAN, Chief

Washington, D. C.

Issued March, 1918

Show this bulletin to a neighbor. Additional copies may be obtained free from the Division of P'ublications, United States Department of Agriculture 
Condtions careaten by the European war have made sheep raising on a small scale a very profitable enterprise for the New Eingland farmer so situated as to take advantage of the ceonomic eonditions.

Prior to the recent remarkable atranee in prices of wool and mutton, sheep raising in New England was comparatively unprofitable, but now, under certain conditions, a revival of the industry seems desirable.

This bulletin tells briefly low the industry was organized in 1911, and diseusses the difficulties to be met in expanding the business, with special reference to improvement in breeding stock, better eare, and more efficient discase eontrol. 


\section{THE PLACE OF SHEEP ON NEW ENGLAND FARMS.}

\begin{tabular}{|c|c|c|c|}
\hline & $\cos$ & NTS. & \\
\hline & Page. & & Page. \\
\hline Purpose of bulletin..... & 3 & Iniprovement of the sheep industry.......... & 13 \\
\hline Conclusions $\ldots \ldots \ldots \ldots \ldots \ldots \ldots \ldots \ldots \ldots$ & $\vdots$ & Possibility for expansion..$\ldots \ldots \ldots \ldots \ldots$. & 16 \\
\hline Present status of the sheep industry in New & & Care of sheep in New England. . . . . . . . . . & 17 \\
\hline England $\ldots \ldots \ldots \ldots \ldots \ldots \ldots \ldots$ & j & 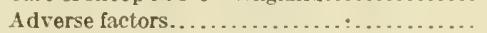 & 23 \\
\hline How the business is conducted ............ & 8 & Size of flock . . . . . . . . . . . & 25 \\
\hline The profitableness of sheep as compared with & & Questions of breeds and breeding............ & 26 \\
\hline dairy cattle prior to $1916 \ldots \ldots . . . . . . .$. & 9 & Sheep on large ranges....................... & 28 \\
\hline $\begin{array}{l}\text { The relative profitableness of sheep and dairy } \\
\text { cattle at present prices...................... }\end{array}$ & 12 & & \\
\hline
\end{tabular}

$\mathrm{R}$

APIDL I CHANGING economic conditions, such as the increase increase in prices of wool and mutton, have induced many farmers in New England. as well as those in other North Itlantic States, to turn their attention with renewed interest to sheep raising. Those already keeping sheep intend to increase the size of their flocks, while others are thinking of putting on sheep. some to the exclusion even of dairy cattle. Present prices of sheep products are attractive and in themselves likely to stimulate interest in sheep raising, and there is no doubt that there are conditions in the eastern part of the country under which an increase in the number of sheep kept is justifiable. However, no material reduction in the number of dairy cows to make place for sheep should be made without a careful consideration of the limitations of the sheep business and the relative returns from each of these live-stock enterprises.

\section{PURPOSE OF BULLETIN.}

Farm management studies conducterl in New England during the summer of 1915 by the Office of Farm Management have made arailable figures which show what the returns from sheep and dairy cattle have been on many farms, and which, when considered in the light of present-day prices, give an excellent indication of what may now be expected from each industry.

It is the purpose of this bulletin to show:

1. The relative importance of the industry and the place that sheep now occupy on New England farms.

2. The returns from sheep as compared with dairy cattle.

3. The more important difficulties experienced by sheep growers and the practices followed in handling these troubles. 
The conclusions arrived at are based on actual fignues obtained from a large number of farms representing the three States in New England in which most sheep are fommd. and npom the opinions of larmer's kecping sheep morler present-rlay conditions. 'The locations of the areas studied are shown in figure 1.

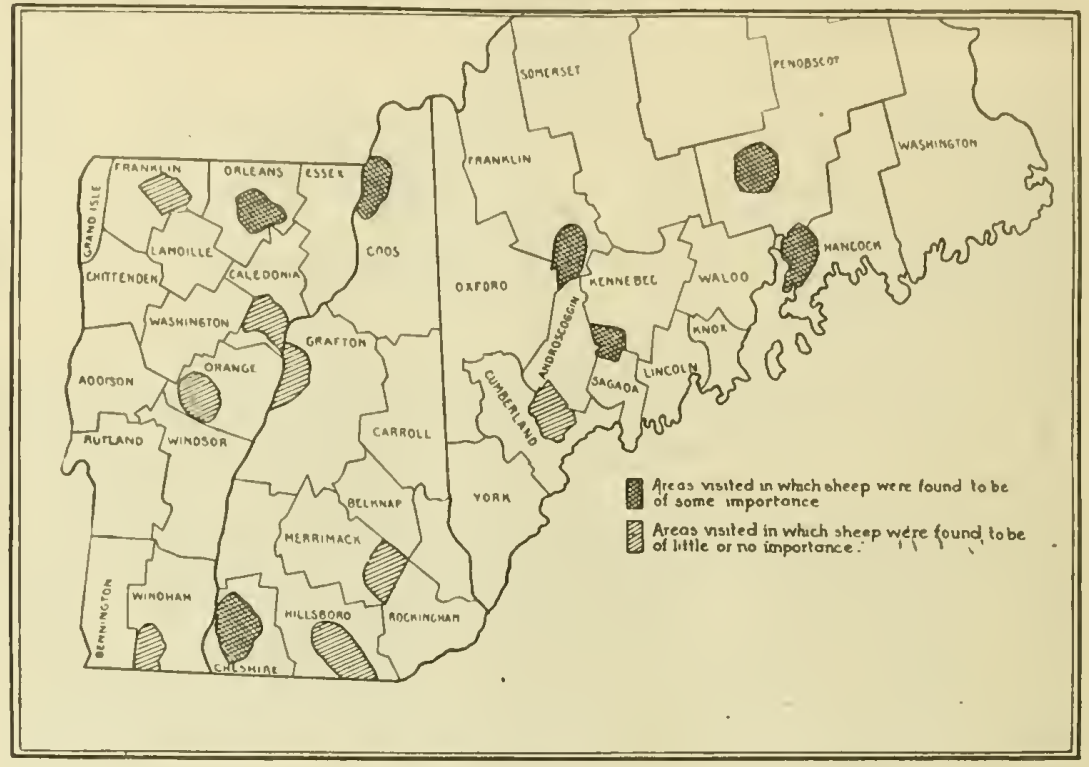

F1G. 1.-Location of areas in New Lingland visited in farm management study of sherp).

AREAS IX WHIII SILET WEHE OF SOMI: IMPORTANE.

\begin{tabular}{|c|c|c|c|c|c|}
\hline State. & County. & Township. & State. & county. & Township. \\
\hline New Hampshire... & 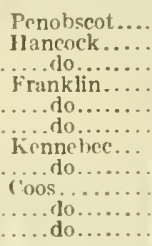 & $\begin{array}{l}\text { Corinth. } \\
\text { Bueksport. } \\
\text { Orland. } \\
\text { Farmington. } \\
\text { Wilton. } \\
\text { Jay. } \\
\text { W'inthrop. } \\
\text { Monmouth. } \\
\text { Stewartstown. } \\
\text { Colebrook. } \\
\text { Columbia. }\end{array}$ & $\begin{array}{l}\text { New Hampshire... } \\
\text { Vermont........... }\end{array}$ & 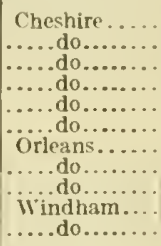 & $\begin{array}{l}\text { Walpole. } \\
\text { Surrey. } \\
\text { Gilsum. } \\
\text { Wiestmoreland } \\
\text { Keene. } \\
\text { Swansey. } \\
\text { Irasburg. } \\
\text { Brownington. } \\
\text { Barton. } \\
\text { W'ilmington. } \\
\text { Whitingham. }\end{array}$ \\
\hline
\end{tabular}

IREAS IX WHIC SIIEEP WYRE OF LITTLE OR NO IMPORTA.TCE.

\begin{tabular}{|c|c|c|c|c|c|}
\hline Maine............. & 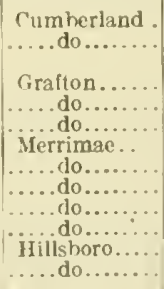 & $\begin{array}{l}\text { Gray. } \\
\text { New rlouces- } \\
\text { ter. } \\
\text { Bath. } \\
\text { Haverhill. } \\
\text { Piermont. } \\
\text { Louden. } \\
\text { Pittsfield. } \\
\text { Chiehester. } \\
\text { Epsom. } \\
\text { Pembroke. } \\
\text { Lyndeshoro. } \\
\text { Amberst. }\end{array}$ & $\begin{array}{l}\text { New IIampshire... } \\
\text { Vermont......... }\end{array}$ & 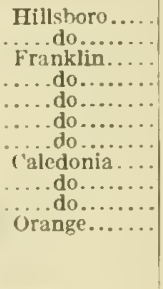 & $\begin{array}{l}\text { Milford. } \\
\text { Hollis. } \\
\text { Franklin. } \\
\text { Berkshire. } \\
\text { Sheldon. } \\
\text { Enosburg. } \\
\text { Bakersfield. } \\
\text { Peacham. } \\
\text { Barnet. } \\
\text { Ryegate. } \\
\text { Randolph. }\end{array}$ \\
\hline
\end{tabular}




\section{CONCLUSIONS.}

Following. in brief, are the more important conclusions drawn from this study:

1. Sheep raising in New England is, at the present time (1917), a relatively small, but. highly profitable business if properly managed.

2. It is believed that the sheep industry could be greatly increased without a material decrease in the number of profitable dairy cows.

3. On most farms adapted to sheep raising, sheep should be kept in small flocks, though much larger than the present average, in conjunction with other kinds of live stock.

4. Sheep, because they require conpparatively little grain and labor, are particularly well adapted to many farms located far from market or to such as have abandoned other forms of live-stock farming because of the high cost of these commodities.

5. As conducted at present. there is great need for the improvement of the sheep industry in New England, particularly with reference to more careful selection of breeding stock, better care, and disease cont rol.

6. Gool care is a rital factor in its bearing upon the profitableness and development of the New England sheep industry, and its importance can not be overemphasized. Except possibly for disease, it is believed more failures in the sheep lusiness are due to lack of proper care than to anything else.

7. The disease factor is one of paramount importance, which, together with low prices, seems to have had much to do with driving the sheep business from the East. and which is still of much concern to the New England sheep breeder.

8. The $\log$ question is a serious one still, but a marked improvement in priblic sentinent is evident and there is good prospect of further legislation designerl to protect the sheep grower in this legard.

9. The question of breed seems comparatively unimportant so long as the sheep kept are of one of the mutton breeds, careful selection and good care counting for more than the breed.

\section{PRESENT STATUS OF THE SHEEP INDUSTRY IN NEW ENGLAND.}

It present less than one-eighth as many sheep are kept in New England as were kept from 65 to 70 rears ago. In 1850 , according to the Federal Census, there were approximately 2.257.600 sheep (exclnsive of lambs) in New England. whereas in 1910 there were only 306.400, the decline having been rather constant during that interval. Since 1910 the reche has continued as previously, and, as estimated by the Department of Agriculture, the number of all sheep in New 
Fingland on Jammary 1, 1918. was but 360,000 . The ratio of this number to the number on hand in 18.50 is as 1 to 6.3 .

Figures obtained for this study check very closely with 1910 census data in showing that at present abont seven-eighths ( 86.7 per cent) of all sheep in New England are found in Maine. New Hampshire, and Vermont. Of these three States, Maine has inore sheep than New Hampshire and Vermont combined. or neirly one-half of all in New England. In Maine practically 1 farmer in every 5 (18.6 per eent) keeps sheep; in New IJampshire and Vermont 1 in every 10 (10.1 per cent), while in the rest of New England as a whole an average of only 1 farmer in 50 keeps sheep. 1 s will be shown later, sheep in any of these States are confined to certain regions, so that the ratio of farmers with sheep to all farms would be somewhat greater in regions where sheep are fornd than is indicated by the fignres given, which apply to the States as a whole.

On the farms on which sheep are kept these animals constitute abont one-fifth of all productive live stock (all live stock except work animals). and at prices prevailing prior to 1916 contributed slightly less than 6 per cent toward total farm receipts. At present prices this pereentage would probably be about donbled.

\section{SHEEP KEPT IN REGIONS RELATIVELY UNFAVORABLE FOR DAIRYING.}

Reference to the map (p.4) shows eight districts visited in which sheep were comparatively important and seven other districts in which sheep were of rery little or no importance. A study of these regions and of the kind of farming carried on in them shows that for the last few rears, at least, sheep in New England have not been kept to any great extent in regions well adapted to dairying and that those regions in which sheep have been most extensively kept are somewhat lacking in the natmal advantages of a typical dairy section.

It must not be inferred from this that dairy farming is of no account in regions where sheep are found. Dairying is carried on on many farms in these regions and, as will be seen later, on farms with sheep, but for the regions as a whole it was found that the keeping of beef cattle was much more common and that the business of dairying was of relatively small importance. Fewer cows were kept in these regions; a considerable portion of the cows kept were of beef hreeds, and dairy products contributed far less toward the total farm receipts than in areas where sheep were of no importance. ${ }^{1}$ In the regions with the sheep one farmer in every five kept beef breeds of cattle, while these breeds are scarcely to be found in the areas

1 Ireas with sheep as a whole had an arerage of only 9 cows per farm, and recelnts from dairy products amounted to lut \$510, while areas where sheep were of no account had an average of 15 cows per farm and receipts from dairy products amounted to $\$ 1,070$. 
studied with no sheep. The relative unimportance of dairying in regions where sheep raising is more common is in large measure due to rougher pasture not so well suited to the needs of dairy stock, remoteness of farms from market, and generally poor market facilities.

\section{KEPT MOSTLY IN SMALL FLOCKS WITH OTHER LIVE STOCK.}

Sheep in New England are kept mostly in small flocks. A few large flocks consisting of 200 or more ewes are known, but such cases are indeed rare. Farm flocks usually number from 15 to 30 ewes, the arerage number on the 137 farms from which records were obtained being 23 . A few farmers kept less than 15 erres while only about 1 farmer in 5 , in the regions studied. kept more than 30 ewes.

Practically all flocks are kept on farms with other live stock. An occasional small farmer who derives the most of his income from the sale of crops or fruit. or from labor off the farm. keeps a small flock of sheep (in addition to a little other stock for family needs) as the only kind of live stock yielding cash income. About one-tenth of the flocks upon which records were obtained were kept in this way; one-half were kept on dairy farms, while the remaining two-fifths were found on farms which kept beef cattle as the principal kind of lire stock.

\section{DO NOT DISPLACE OTHER KINDS OF LIVE STOCK.}

Kept in these sinall numbers, sheep do not displace other kinds of live stock. but are kept in addition to the regular quota of other stock on such farms as have extra pasture available. It was found that, regardless of whether sheep were kept in conjunction with dairy or with beef eattle. farms with sheep had practically the same kinds and numbers of other live stock as did farms without sheep. ${ }^{1}$ Moreover, farms with the sheep had an average of 15 more acres of past ure than did farms without the sheep, ${ }^{2}$ warranting the conclusion that sheep in New England hare not been kept to the exclusion of other live stock. but have been kept on farms with large pasture areas to utilize the extra pasture a vailable.

\footnotetext{
${ }^{1}$ In making this determination it was first found that swine and poultry, which do not usualiy require pasture as kept in New kngland, were kept in about the same numbers on farms regardless of sheep. Ail cattie were then reduced to a mature animai basis fcounting 2 head of young cattle as the equivalent of a nature cow and the average number of pasturabie animals (mature auimai basis) determined for farms with aud for farms without sheep. Following this method, it was found that 68 dairy farms on which sheep were kept had on an average the equivalent of 16.1 mature cattle in addition to 22 sheep. while 298 dairy farms of comparable size. but without the sheep, had the equiralent of 16.3 mature cattle. Likewise $\mathbf{5} 4$ farms keeping sheep in conjunction with beef cattle had ou an average the equivalint of $\mathbf{1 5 . 4}$ mature cattle in addition to 24 sheep, while 60 beef-cattle farms without the sheep had the equivalent of $\mathbf{1 5 . 5}$ mature cattle.

$=$ larms with sheep had an uverye of 85 acres of pasture, while those without sheep had 70 acres.
} 


\section{SHEEP FOUND ON I,ARGE FARMS WITI LOW.PRICED LAND.}

Pasture is a prine esential to sheep raising, ant it has been shown that only such farms as lave pasture above the needs of other stock have kept sheep. As wonkl be expected from the nature of New England land, such a pasture exeess is to be found on the larger farms only. In the areas studied sheep are scareely ever kept on farms of under 100 acres. ${ }^{1}$ On farms above this size. flocks gradually becune. more common. occupying the most prominent place as a farm enterprise on farms of 200 acres or more, where they are kept on about one farm in every three and in eonparatively large flocks. The 122.2 farms keeping sheep with the other stock had an average area of 219 acres, while 358 firms, falling within the same sized limits and similarly organized except for the sheep, lat an average area of only 179 acres.

It was found. moreover, as to character of the land area, that these larger farms with sheep have, for the most part, practically the sane acreage in crops as farms without sheep, but a relatively higher percentage of pasture and woodland, resulting in a lower land value per acre. Land values on farms on which sheep were found in all three States averaged \$o.n per acre. whereas the a verage value on the small farms without sheep was $\$ 29$ per acre. ${ }^{2}$

\section{HOW THE BUSINESS IS CONDLCTED.}

For the year 1914, 30 per cent of the receipts from sheep on the 137 furms stuclied were derived from the sale of wool: 62 per cent from lambs, and the remaining 8 per cent from the sale of old ewes and increase in inventory value above purchases. At presentday prices with the same production (1917), the receipts from wool would increase to about 40 per cent of the total and those from lambs and ewes decrease proportionately, since the price of wool has increased more rapiclly than that of mutton. These figures give an idea of the kind of business carried on. Practically all breeders included in the sturly were producing spring lanbs which were nurketed in the late summer or fall at the age of 5 or 6 months, though an occasional breeder was supplying a special trade with fall or early winter lambs marketed in the spring. Practically all sheep were gratles, the medium-wool "down" breeds being the most common. though some of the flocks wore batly mixed and. as their owners said, they kept " just sheep."

\footnotetext{
1 The few flocks previously referred to as being kept by small farmers were kept on farms of this sizr.

2 Only from on r-fourth to one-tlind of the land area of New lingland farms is sultable for cultivation.
} 


\section{REPLACEMENT AND DEPRECIATION.}

The transactions and changes affecting the 137 flocks of sheep give an idea of the depreciation, and of the replacement necessary in order to maintain a flock of sheep in a normal year when little disease occurs. Of all the sheep on the 137 farms at the beginning of the year (Apr. 1, 1914) 10.9 per cent were sold as old sheep, 4.4 per cent died, and 0.8 of 1 per cent were slaughtered, making a total of 16.1 per cent, nearly 1 sheep in every 6 , which were either disposed of or died during the year. Of the sheep in the flocks at the end of the year (Mar. 31, 1915) 11.3 per cent were yearlings (lambs of the prerious year), while 3.4 per cent were purchased, the total replacement being slightly less than the sales and casualties and resulting in a slightly decreased inventory.

These figures, which are believed to be representative for a year in which little disease occurs. show that in order to maintain a flock of sheep without any decrease in number, it is necessary to replace about one-sixth of the flock each year and that, except for the rams, this replacenent consists largely of lambs raised on the place. A loss by death of slightly less than one sheep in 20 can be normally expected, while slightly more than one lamb in 20 dies after having made considerable growth, to say nothing of the deaths occurring at and shortly after birth.

\section{PRODUCTION AND PRICES.}

As to production in 1914 , each sheep sheared an arerage of 6.5 pounds of wool, and 75 lambs were raised for every 100 sheep kept. ${ }^{1}$ Eleven of the 75 lambs raised were retained in the flock to replace old erres, learing unly $6+$ lambs to be marketed for every 100 sheep kept. In addition to the receipts from the sale of wool and lambs, an average of 11 old ewes were sold for erery 100 sheep kept.

The arerage price received for wool was 22 cents, and lambs at that time brought from $f$ cents to $6 \frac{1}{2}$ cents per pouncl. live weight, a veraging $\$$ t.6i3 each for all sold. The arerage inventory price for mature sheep at the beginning of the vear. April 1, 1914, was \$..24, and $\$ 5.50$ at the end of the year, March 31, 1915. Discarded ewes were sold at an arerage price of $\$+.10$ each, while $\$ \pi .04$ was the arerage price paid for sheep purchased, which were mostly bucks.

\section{THE PROFITABLENESS OF SHEEP AS COMPARED IVITH DAIRY CATTLE PRIOR TO $1916 .{ }^{2}$}

THE ANIMAL UNIT AS A BASIS OF COMPARISON.

In order to compare the relative returns from the various kinds of live stock some standard of comparision has to be adopted. and to

1 This number probally included about 10 searling ewes which lad no lambs, and in ardition to the 75 lambs raised, 4 diod after liavine made considerable wrowth, so tliat the lambing rate fol the ewes hred was nearer si pel cent tlan 65 prer rent.

2 While the study is based on figures pertaining to the $191 \pm$ busiuess year, prices of sheep products did not change matrially until 1916, so that the figures apply to the year $191 \%$ as well as 1914 . $33388^{\circ}-1 S-$ Bull. $929-2$ 
this end use has been made of what is termer an animal unit. $\Lambda \mathrm{n}$ animal unit as here used is a standard unit to which all classes of stock are reduced for means of comparison, and is based upon the amount of feed required by each class of animals when kept under usual farm conditions. It has been found that 1 mature horse or cow, 2 hearl of young cattle, 7 sheep, or 5 hogs consume in the course of a year approximately the same amounts of feed, hence those numbers ${ }^{1}$ for the classes of stock given are taken as constituting one animal unit.

In the discussion to follow an animal unit of sheep may be thought of as 7 ewes ( 6 of breeding age and 1 yearling) in addition to their lambs raised to the age of 5 or 6 months. An animal unit of dairy stock in a similar way consists in part of young cattle as well as mature animals, and it is the animal unit of dairy stock rather than a single cow that should be kept in mind in the following pages.

\section{RECEIPTS FROM TIIE TWO ENTERPRISES.}

With prices and production as previously given, the average receipts per head of sheep kept (yearlings included) were $\$ 1.78 .^{2} \mathrm{At}$ this rate, assuming 7 heal of sheep equivalent to an animal unit, the receipts per animal unit of sheep under prices and production prior to 1916 were $\$ 33.46$. The receipts ${ }^{3}$ per animal unit of dairy s.tock, on the other hand, were $\$ 67.12$, not including $\$ 8.40$, the estimated ralue of unmarketel skim milk which could have been sold at 40 cents per hundred weight, ${ }^{4}$ making a total of $\$ 75.52$.

1 While the numbers given hold in a general way, adjustment has sometimes to be made to meet the varylng brecls and conditions of different regions under which stock is kept. For example, in the case of sheep, where a considerable portion of the lambs frowth is made on fceds other than their mother's milk, requiring extra feeding of eitler the lambs or ewes, allowance has to be madc, in which case, figured on the basls of mature shecp, the number constituting an animal unit would be somewhat less than seven. After having glren this point careful consideration it has been decided that as sheep are kept in New England, most lambs being boln in the spring of the year and marketed in the fall, seven ewes (ycarlings included), raislng what lambs. they may, is the right number to use as constluting onc animal unit.

2 Includes the following:

Wool, 6.5 pounds at $\$ 0.22 \ldots \ldots 1.43$

Lamb, 64 pcr 100 sheep at $\$ 4.63$

Old ewes and inventory increase

Total. per sheep_._. $\overline{78}$

${ }^{3}$ The arerage production of dairy cows in the regions in which sheep werc kept and with which the comparison of profits is made was sllghtly less than 200 pounds of butter fat, or a little less than 5,000 pounds of 4 per cent mllk. Cream and butter constituted by far the most important classes of dairy products sold, though some whole milk was marketed on a butter-fat hasis. Wherc cream or butter was sold the skim milk was fed on the place and an estimate of the value of that fed to stock other than the cattle made as contributIng to recefpts. About 75 per cent of all receipts from the dairy were derived from the sale of milk, butter, or cream, and the remaining 25 per cent from sales of stock. The average price received for hutter fat for the year in question was $\$ 0.34 \overline{5}$, and butter sold at a proportlonate price.

"The average price pald for skim milk in $1914 \mathrm{by}$ creameries in the localitics studled, in addition to that paid for butter fat included when buying whole milk. 
cost's.

While the data furnished by the survey study are not complete enough to make possible a detailed study of the cost of conducting either the sheep or the dairy industry, taken with other data obtained for the purpose it is sufficiently complete to give a fair indication of the major expense items which are of most concern to the arerage farmer and have the most pronounced bearing upon profits. Hence the discussion of costs to follow, which is admitted to be incomplete, is presented only as an intermediate step in determining relative profits of the two industries.

Figures arailable representing the arerage value of feed consumed per animal unit by all stock on farms with and without sheep, indicate that an animal unit of sheep and dairy stock in New England each consume in the course of a year practically the same amount of roughage other than pasture, but that the dairy stock require many times more grain than do the sheep. As nearly as can be estimated from the data at hand, the total average feed cost per animal unit of sheep above pasture for the year 1914 was $\$ 32.20 .^{1}$ The estimated feed cost per animal unit of dairy stock on the other hand was $\$ 18.90 .^{2}$

As to pasture, the value of that furnished the sheep in late summer and not furnished the cows has already been included in the feed cost under the head of supplementary forage crops. Further than this no attempt will be made to estimate the ralue of pasture, as it is believed that this cost per animal unit is practically the same for either sheep or dairy cattle and that for the purpose of comparing returns it can well be omitted.

Labor, as nearly as can be estimaterl, cost about $\$ 6.30$ per animal unit of sheep as compared with $\$ 18.45$ per animal unit of dairy stock. This allows for 4.2 days of man labor per year per animal unit of sheep and 12.3 days for the dairy stock, the rate in either case being $\$ 1.50$ per day, which, according to survey figures, was the arerage prevailing day wage paid in those regions in 1914.

The feed and labor costs together total $\$ 38.50$ per animal unit of sheep, and $\$ 67.35$ per animal unit of dairy stock.

\footnotetext{
1 Includes :

$1 \mathrm{lay}, 2$ tons, at $\$ 11.40 \ldots 0$

Straw and stover, 0.2 ton, at $\$ 5$

Ronts, $T$ bushels, at $\$ 0.10 \ldots$

Supplementary forage crops

Grain feed, 280 pounds, at $\$ 1.50$ per hundredweight_............ 4.20

2 Includes :

IIay, 2 tons. at $\$ 11.40$

Straw and stover, 0.2 ton, at $\$ 5 \ldots$

Silage, 1.1 tons, at $\$ 3.75$

Grain feed, 1,400 pounds, at $\$ 1.50$ per hundredweight............ 21.00 


\section{RELATIVE; PROFITS.}

Subtracting the combined feed and habor costs (\$38.50 per animal unit for the sheep and sit.35 for the dairy cattle) from the respective receipts ${ }^{1}(\$ 33.46$ and $\$ 5.5 .52)$, it is found that the receipts from sheep lacked about \$.5 (\$5.0.t) per animal unit of paying for the feed and labor cost, while the dairy stoek left a margin of slightly more than \$8 (\$8.17) over these costs. In other worels, if home-grown feeds be charged at farm value, ${ }^{2}$ with feeds purchased at cost and labor at the prevailing wage, sheep, muler price and production conditions prevailing prior to 1916 scarcely more than paid for the fecal consumed during the fall, winter, and spring months (to say nothing of labor, summer pasture, and other costs), ${ }^{3}$ while dairy stock paid for both feed and labor and left a margin just about equal to the value of unmarketed skim milk, which would go a consiclerable way in offsetting the pasture and overhead costs. Had the prodnction of lambs been at the rate of 100 per cent rather than 75 per cent, and the clip of wool been 1 pound greater per sheep, the returns from sheep would have compared much more favolably with those fron dairy cattle. It was the opinion of the majority of farmers that sheep were paying better during the period to which the data pertains than formerly. This evidence, together with the figures presented, indicating that dairy cattle were rolatively more profitable than sheep for the periorl just prior to 1916, strongly indicates at least one good reason why the sheep industry declined in the East.

\section{THE RELATIVE PROFITABLENESS OF SHEEP AND DAIRY CATTLE AT PRESENT PRICES.}

The fignres given aloove showing lelative returns from sheep and dairy cattle are based on prices and production prevailing prior to 1916. From a recent interview the same production still holds. but under present prices, quite another story as to relative profitableness of the two industries would be told. For the present season wool has about trebled in price, ${ }^{4}$ while the price of lambs has about

1 These receipts include no estimate of the value of manure produced, hut it is bellered that this ls about the same per animal unit of sleep as per animal unit of dairy stock. and that this would in no way change the conclusions as to relative profits of the two kinds of live stock.

3 Market ralue less the cost of marketing. In case of hay, less the cost of baling and hatulin: to market.

3 lneludes lnterest. use of buldings. and any uninor special rosts. lepreciation and use of sire, other expense ftems usually included in the eost of eonducting a live-stoek enterprise. are eliminated, as with thr method employed thes are taken aecount of in figurlng receipts: that ls, the sire in each rase las heen included with the rest of the stock in figuring animal units, and the receipts per animal unit represent returns ovel losses and dereased value of loreeding stock.

- While a few furmers in New logland have eccelved as high as io conts per pound for this segson's wool. others $w$ ho sold early reepired no more than 5.5 cents, so that it is bolieved that the bulk of the 1917 clip was sold for no more than 66 cents per pound. which is three times as great as the 1911 price. 
doubled. The price received by farmers for dairy products, on the other hand, has increased by about 40 per cent during the same period. ${ }^{1}$

As to costs, grains most commonly fed in these regions have increased in price by about 75 per cent ${ }^{2}$ roughage has remained at about the same price (due probably to the large hay crops of the last two years in the regions studied); while labor has increased by about $33 \frac{1}{3}$ per cent ${ }^{3}$ of the former cost.

At present prices, then, assuming the same production from sheep on the one hand and from dairy stock on the other, the gross returns per animal unit of sheep would be $\$ 76.93$ instead of $\$ 33.46$, and from the dairy stock $\$ 101.37$ instead of $\$ 75.52$. The combined feerl and labor costs for the sheep, assuming the same amounts but present prices, would increase from $\$ 38.50$ to $\$ 43.75$ and for the dairy stock from $\$ 67.35$ to $\$ 88.65$. At these prices the net profit over feerl (except pasture) and labor cost per animal unit of sheep are approximately $\$ 33.18$, as compared with $\$ 12.72$ from dairy stock, showing that at present, sheep are far more profitable, in small flocks at least, than dairy stock. Prices for sheep products, due no doubt to conditions caused by the war, have increased far more in proportion than have those for dairy products; and furthermore. sheep stand decidedly in faror at present because of requiring relatively little grain ieed and labor, the costs of which have increased greatly, while roughage, which forms by far the greatest expense in the cost of keeping sheep, has not increased materially in value-in New England at least.

\section{IMPROVEMENT OF THE SHEEP INDUSTRY.}

Though sheep raising as now conducted on the farms studied is a profitable business at present prices, the writer, judging from the

\footnotetext{
1 For the two perlods of nine months each, ending $\Delta$ ug. 31, 1914, and Aug. 31, 1915, respectively, the Turner Center Creamery, at Auburn, Me., paid an average price of $\$ 1.78$ per hundredweight for whole milk testing 4 per cent butter fat, whlle for the same period ending Aug. 31, 1917, the averaze price paid by the same concern for the same grade of milk was $\$ 2.49$ per hundrellwelght, or an increase of practically 40 per cent. A large part of the dairy products in the regions studied in Maine were sold to the concern men. tioned, and it is believed that this increase in price of milk is representative of the increase in areas studied In New llampshire and Vermont as well. A nine months' period instead of a full year was used in making the comparison, as only that lengtll of time up to Sept. 1, 1917, had elapsed since the price of mllk had increased inaterlally.

2 These Incrcases are based on figures obtained at the time the survey was made, together with a knowledge of the prices paid during the past spring aud summer. The price paid for grain feed in 1914 was about $\$ 30$ per ton. All increase of 75 per cent over this amount, to $\$ 52.50$ per ton, is believed to represent not far from the average prlce pald for what feed was purchased in the regions studied during a nine months' period ending Aug. 31, 1917.

"The average value of labor (farmer's time included) in the regions studied for the year 1914 was about $\$ 36$ per month, including that part (about one-half) of a man's board not produced on the farm. An increase of 333 per cent, or $\$ 48$ per montli, is belleved to cover fully the value of labor spent ou the two classes of live stock concerned during the past year.
} 
experiences of many growers, is convinced that there is moln room and areat need for the improvement of the sherp) industry in New England and that the average grower conkl, with better care, make the business a nuch more profitable one, even under normal conditions and without the artificial stimulus to prices given by the war.

\section{INCREASING TIIE LAMBING RATE.}

One way of increasing profits is by increasing the lambing late, which, as will be rememlered, was only 75 per cent (on basis of all sheep kept and lambs laised) for the vear to which the data pertain. This low rate seems die to three or four reasoms, all of which could with better care and closer attention be casily obviated.

In the first place, some breeders are carcless about breeding and often fail to get the ram witl the flock at the proper tine, with the result that many ewes go unbred. Others fail to provide sulficient and snitable feed to keep their stock at all times in good condition, which is as essential at and before breeding time as during pregmancy. Some fail to give the close attention necessary at lanbing time, while still others are careless about the selection of breeding stock, keeping in their flocks small, immature ewe laubs (in many cases selling their best ones) and old decrepit ewes which might better have been discarded. It is known that loss results from all these sonrces and that each contributes toward decreasing the number of lambs born, to say notling of the deaths that occur at and after birth. Also it is believed that mich could be accomplished in the way of. increasing the lambing rate through selection, retaining for breeding the offspring of the more prolific ewes that are sure breeders, good milkers, and good mothers.

With closer attention to the factors enumerated it is believed that the lambing rate can be increased so that 100 lambs can be raised per 100 sheep kept rather than 75 , as was the case in 1914 . In order to attain this standard, assuming a sixth of the flock to be yearling ewes. which in most cases would not be bred, and allowing for a normal death rate of 5 per cent after lambs are started, it will be necessary for every ewe of breeding age to raise at least one lamb and about a quarter of the number to raise a pair. Many of the better breeders are already raising considerably more than this number, and the standard seems a reasonable one to strive for. Such an increase in lambing rate (from 75 to 100 per cent) would allow 25 more lambs to be marketed for every 100 sheep kept. which at present prices would mean an increase in receipts of $\$ 2.32$ per sheep, or $\$ 16.24$ per animal unit of sheep.

\section{INCREASING THE CLIP.}

The arerage fleece clipped per sheep in 1914 was only 6.5 pounds. It is believed that by eloser selection of stock, eliminating, as before 
suggested, all small, immature ewe lambs, as well as old ewes, and with better care, that this average could be raised by at least 1 pound, especially where sheep are kept in such small flocks as in New England. Growers agree that sheep well fed and cared for throughout the year shear more wool than do those not well cared for, and it is generally realized that in order to produce a good fleece it is essential to keep a sheep in good condition. They also think that sheep kept in sulall flocks, probably because of the better care received, produce more wool than when kept in larger flocks, and it is known that some of the growers, even with the mutton breeds, arerage over 8 pounds of wool per head. An increase of 1 pound of wool per head at present prices means an increase of about 66 cents per sheep, or $\$ 4.62$ per animal unit of sheep.

\section{EFFECT ON PROFITS.}

A one-third increase in lamb production (from 75 to 100 lambs per 100 sheep) and a 15 per cent increase in wool clipped per head (from 6.5 to 7.5 pounds) means, at present prices, an increase in receipts of nearly $\$ 3$ per sheep, or $\$ 20.86$ per animal unit. It is not expected that this increased production can be attained without an increase in cost, which, however, would be nowhere near in proportion to the increase in receipts. Allowing for the increased labor and feed beliered to be necessary ${ }^{1}$ increases the feed and labor cost at present prices from $\$ 43.75$, the estimated cost with present production, to $\$ 50$ per animal unit. The estimated receipts being increased from $\$ 76.93$ to $\$ 97.79$ as a result of the increased production, leaves a profit over feed and labor cost of $\$ 47.79$ per animal unit of sheep instead of $\$ 33.18$, the profit at present production.

In order to do the dairy industry no injustice in making this comparison, an increased production of 20 per cent, or cows producing 6,000 pounds of 4 per cent milk. which is as reasonable an increase as that assumed for the sheep, has been assumed. Allowing for the increased feed necessary ${ }^{2}$ with this production increases the cost as estimated at present prices from $\$ 88.65$ to $\$ 99.85$ per animal unit. The receipts being increased from $\$ 101.37$ to $\$ 117.60$ as a result of increased production leaves a profit orer feed and labor cost of $\$ 17.75$ per animal unit instead of $\$ 12.72$, the profit at present production.

Increasing the production of the sheep and of the dairy cattle as indicated, while not changing the relative profitableness of the two industries, increases the profits over feed and labor cost in either case

\footnotetext{
1 In making up this estlmate of feed and labor cost necessary for the increased production, allowance for the following increases per 7 sheep (anlmal unit) were made: Roots, from 7 to 35 bushels; grain feed, from 280 to 350 pounds; labor, from 4.2 to 5 days.

2 Allows for a slight Increase in the amount of sllage and increases the amount of grain from 1,400 pounds to 1,800 pounds.
} 
by abont 40 pere cent, making these profits from the shepp busines. which it must be remembered is a relatively small industry, \$47.7? per animal mit as compared with $\$ 17.55$ pel animal mit of dairy stock.

\section{POSSIBILITY FOR EXPANSION.}

I considerable expansion of the sheep andustry in New England is 110 doubt justifiable. The above fignres and previous ones show that sheep, in small flocks at least, are more profitable than dairy cattle at the present time (1917). It must not be inferred from thin that the shoep industry should to any weat extent displace the dairy industry, but it is believed that expansion can be made through other channels without lecreasing the output of dairy products or disturbing the economics of the region so far as the dairy business is concerned. One's decision to keep sheep must not be hased entirely upou the strength of the profit figures shown, as either business is subject to constantly changing prices which at the present time point to a far narowel difference in profits from the two industries than is indicated by the figures given. ${ }^{1}$ Also it must be remembered that the figmes given are based on records from comparatively small flocks only. Displacing any great number of dairy cows by their full equivaleut in sheep mean keeping sheep in large numbers, and, as will be shown later, there seems plenty of eridence to support the belief that sheep thus kept in New Engiand are in no wise as profitable as small flocks.

Is to channels of expansion, it is known that there are many unprofitable dairy cows in New England and that many of these conld probably well be replaced with sheep. However, where poor care on the part of the owner is the main reason for the unprofitableness of the cow, it is likely that sheep would be quite as unplofitable. and before making any replacement the cause of the unprofitableness should in all cases be determined. Some farms are located so far from market as to make their operation as dairy farms impracticable, while other operators have abandoned the dairy business because of the difficulty of securing help. 'These two classes of farms offer much room for the expansion of the sheep industry and, if rightly managed, there is little doubt that sheep would prove much more profitable than beef cattle, which at present constitute most of the live stock on such farms. Some other fams in addition to the classes mentioned could carry a small flock of sheep in addition to the regular anount of stock, but careful consideration should be given the pasture requirement to make sure that this does not lead to overstocking.

1 The price of milk in New England was adranced 1 cent a quart, or about in cents per lundredweight, for the months of August and September and the first half of October. while a stlll further advance of 1 cent a quart was made to be effectlve from 0 ct. 15 to Dec. $1,1917$. 


\section{CARE OF SHEEP IN NEW ENGLAND.} IMPORTANCE OF GOOD CARE.

Judging from the experiences and observations of the growers included in this study, it would appear that care is the most important factor bearing upon the profitableness of the sheep business in New England, and its bearing upon several sources of loss has alrearly been touched upon. Excepting possibly disease, which is to a large (xtent aroidable, it is believed that more losses in the sheep business are due to lack of good care and feed than to any other one thing. Although sheep may be salicl to function to some extent as scar(enger's-and too many make the mistake of feeding on the assumption that sheep can thrive eating weeds and cleaning up fence rows and wastelands-like any other animals they must have good care if good results are to be expecter from them.

The requisites of good care for sheep ${ }^{2}$ may be briefly enumerated as follows: Plenty of wholesome feer at all times: dry quarters, good ventilation, and an opportunity to exercise while being stabled: and close attention at lambing time. Occasional inspection and regular: dipping is also essential to insure freedom from lice, ticks, and skin diseases.

\section{SUMMER FEEDS.}

As to feeds, in most cases sheep in New England require during the summer months nothing but good pasture. In the more farored sections of New England. Where natural grazing land (see fig. ․․)

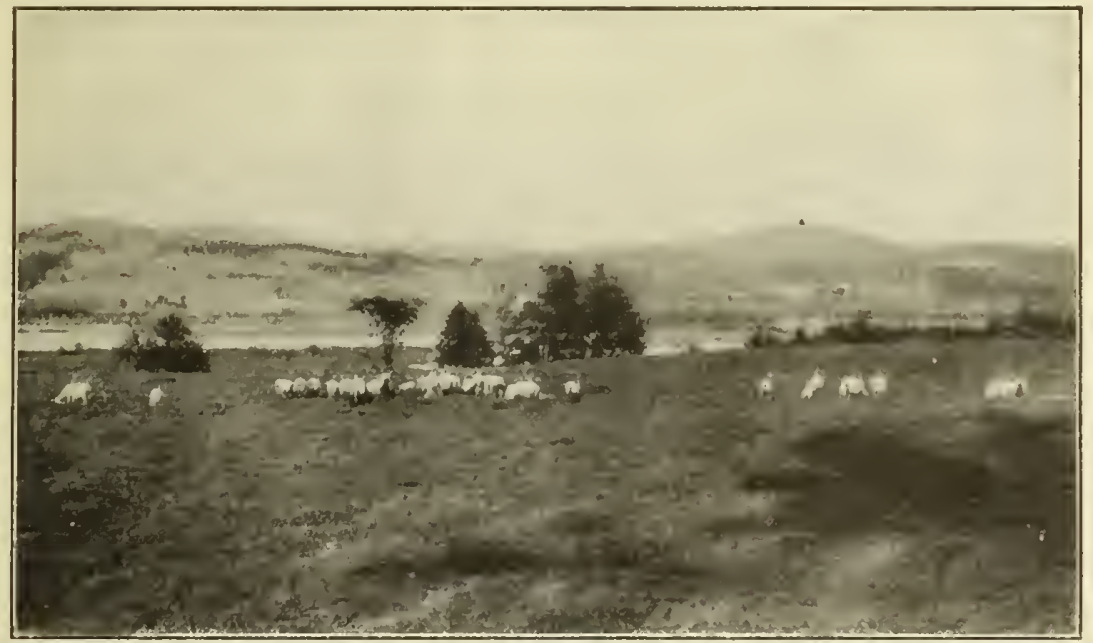

Fig, 2.- Sluepel grazing on a luxuriant bluegrass pasture in Vermont. such pastures, which are the exception rather than the rute in New England, do not need to be supplemented with forage crops until late in the season, and sometimes carry the breeding stock througb the entire pasture scason without supplementary pasture.

'The care of the farm flock is fully discussed in Farmers' Bulletln s40, which is obtail1. abte upon recuest from the Departuent of Anriculture. 


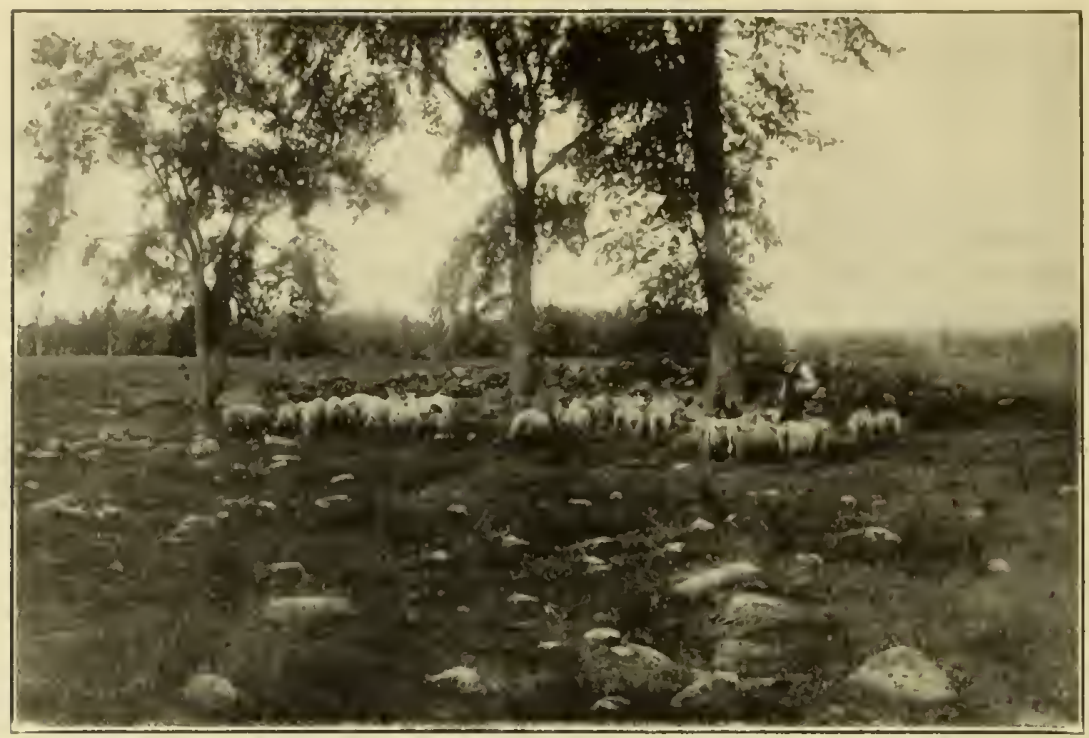

Fri. :- A llock scene at salting the. The rough, stony pasture, whlch is more typlenl of New England than the one shown in tigure 2, afforls consiclerable feed, but has to be supplemented by other feed much sooner. The mistake is often made of leaving sheep ou such pastures two hat in the season, which is good for nelther the sheep nor the pasture.

is to be had, but little other pasture is necessary. In less favored sections, where pastmes do not hold out throughout the summe: (see fig. 3), other feed shonld be provided. "It las been found inpractical in most cases to keep sheep in New England unless pasturage ean be depended upon during the entire pasture season, or at least until after the field crops are harvested, when the sheep can le allowed for a time the run of the entire farm. Some make a practice of pastming sheep with other stock, while others prefer to have them alone. Sheep are known to eat a great variety of herbage, and the majority agree that sheep render a valuable service in keeping down weerls that cows will not eat. On the other hand, it is known that sheep crop much closer than do cows, and it is agreed by the majority that for this reason cows do not do as well, unless the pasturage is luxuriant, when pastured with sheep.

It is especially important that plenty of pasture be provided during the late smmmer and fall when the lambs need to be put in shape for market and the rest of the flock kept in the best of condition for breerling. It this season of the year the regular pastures misnally afford lout little feed, and that of an inferior quality, so that it is necessary for good results to make provision for other than the regular pasture. I good practice among many growers is to separate the lambs from the ewes abont a month before marketing time, pasturing the lambs on second-growth clover, or in many instances 
allowing them the run of the entire farm, and keeping the ewes on the old pasture until after the lambs have been turned off, when the ewes also are allowed the run of the farm. This practice works out satisfactorily where extra fencing for the sheep is not necessiry and where the old pasture affords sufficient feed to keep the breeding stock in good condition until they can be allowed the run of the place.

A safer practice, which is already being followed by a few of the more successful growers and which is to be highly recommended, is the growing of some forage crop for late summer and early fall pasture. Rape makes an excellent crop for this purpose and is one well adapted to New England conditions. To give best results rape should be sown on good land, loam preferred, which is not subject to drought, since the crop often fails in dry seasons. If raised on weedy land the seed should be sown in drills 30 inches apart at the rate of 1 to $1 \frac{1}{2}$ pounds per acre and the plants regularly cultivated, while if on land free from weeds, broadcast seeding at the rate of from 2 to 3 pounds per acre gives satisfactory results. The crop can be grown alone or, if on clean land, with another crop such as oats or rye or following a crop of corn (see fig. 4), in which case the seed is sown broadcast or in drills between the rows of corn at the last cultivation. Where early feed is desired, and the land can

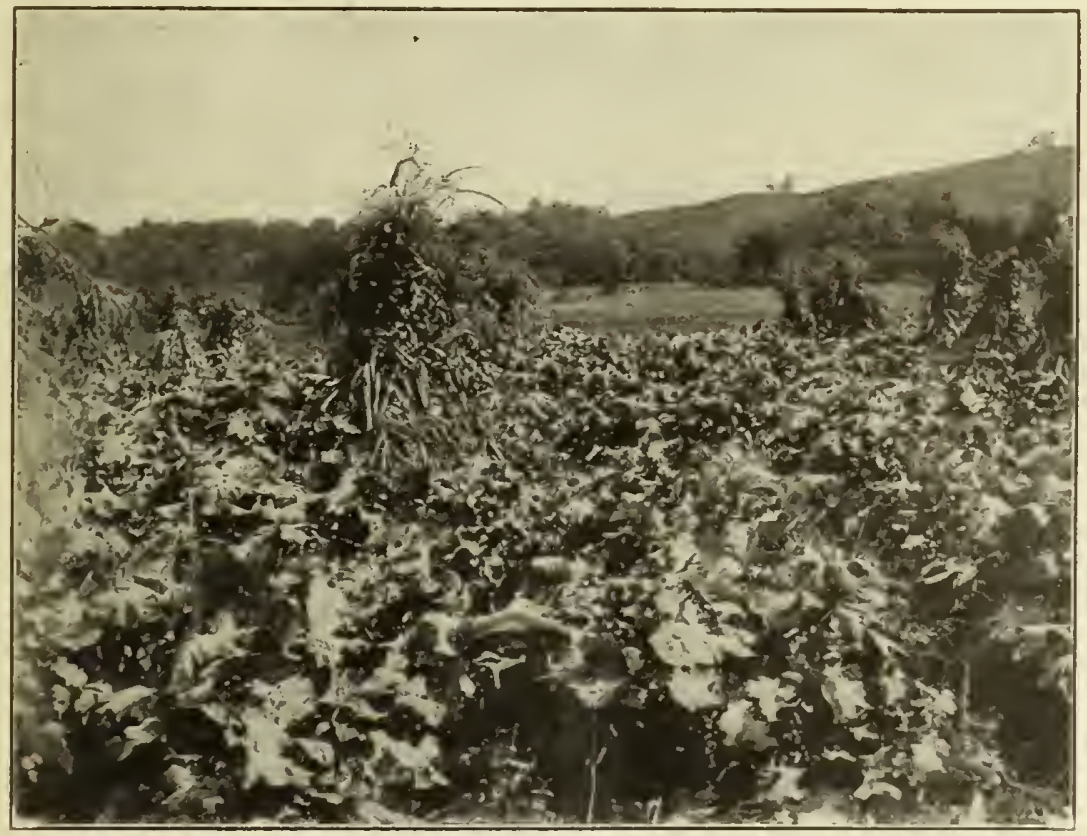

FIg. 4.-Rape grown in corn to be used for fall pasturage in fattening lambs. The seed was suwn in the corn at the last cultivation at the rate of 1 pound per acre. Two acres of sueb feed will normally fatten 40 lambs. 


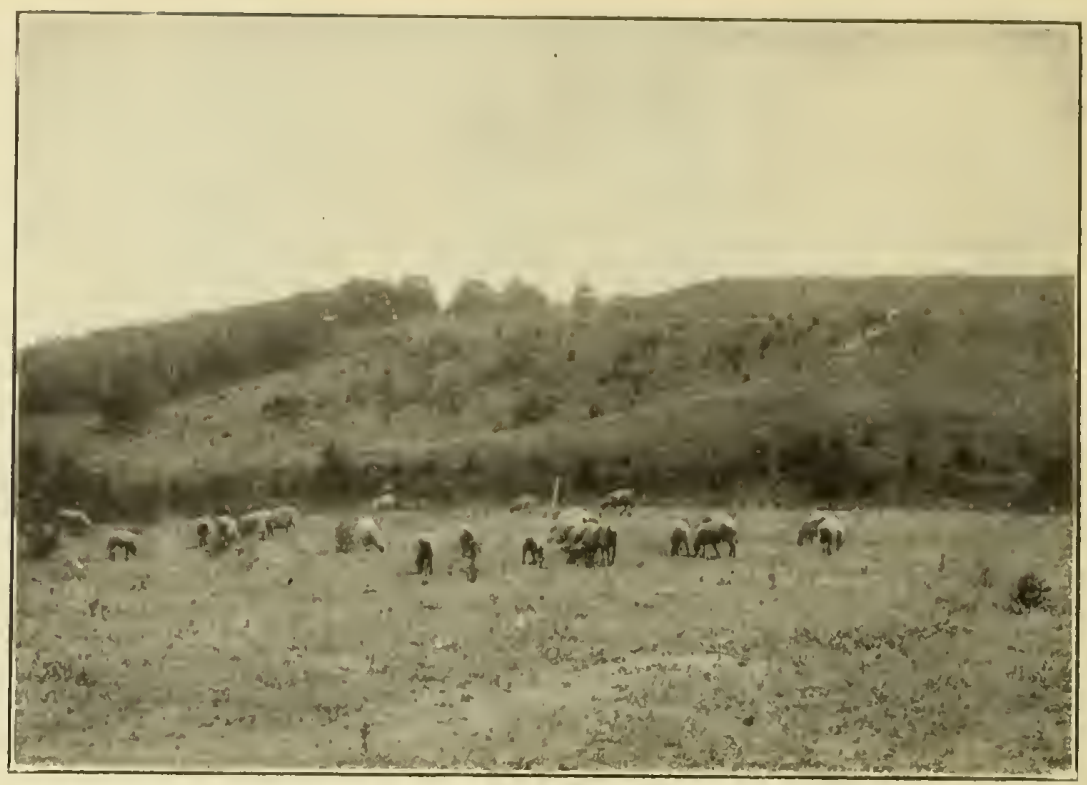

Fil; 5.- Lives and lambs pasturing on rape, which has been practicaliy all eated ofl. This crop, which was sown alon" for "arly fall feeding, was used to supplement the typical New England pasture shown in tho backround.

be spared, it is probably best to raise the cop alone (see fig. 5), but if the feed is not neerled until some little time after corn is mornally cut, the latter practice answer's the purpose as well. In New England a periorl of from 8 to 12 weeks sliould be allowed from the time of sowing the seed until the crop is ready to feed. If sown alone in early May and cultivated, feel slrould be afforded by the latter part of July, while a seeding in corn fron July 1 to 15 ought to provide October and later fall feeding as long as needed. much of the growth being made after the corn is cut. Cultivation induces growtl and increases the yield, though the results obtained by seeding corn on gool land are very satisfactory.

One acre of the crop grown alone, or 2 acres following corn, is usually sifficient to fatien from 30 to 40 lambs if allowed the rm of other fields, as is usually the practice where rape is grown. Care should be taken in regard to bloating, when first turning sheep into a field of rape, but after the first few feeds no trouble need be expected. This crop, if more generally grown would do much toward solving the fall feed question and should be more extensively used where sheep are kept.

\section{WINTER FEEDS.}

Is to winter feeds, any one of the finer lrays makes gool forage for sheap. Legrumes are to be preferred if not too coarse, coarse hays making poor feeds for sheep. Alsike Clover in particular is to be 
recommended, while large Mammoth Clover is too coarse. Some make use of this, howerer, by allowing the sheep to pick it over and eat only what they want, feeding the coarser parts to other stock. "Rowen," as it is known in New Fngland, or the aftermath from lay lands, is said to make an excellent feed for sheep, and many plan to save their rowen to feed the sheep just prior to and at lambing time. Rerltop, fine lowland hay, and what is known locally in many places as Jume grass, all make good sheep hays, whereas “- Herds Grass" (timothy), millet, and other coarse hays a re not to be desired.

In addition to dry" roughage, some form of succulent feed should be provided. This form of feed is too often lacking; but it is particularly essential in keeping sheep in good condition during the winter, and if fed with the right kind of hays probably reduces considerably the amount of grain required. For New England, probably nothing is better than rutabaga turnips (see fig. 6) for this elass of feerl. Sweet apples are sometimes ferl in the place of or to supplement roots, with good results. Corn silage is available on many farms and could be used as a succulent feed for shrep mueh more extensively than it is.

Practically the only grain fed to the farm flock in New England is ferl just prior to and at lambing time, and mo-t growers agree that some grain at that time is essential. Whole or ground oats and wheat bran. sometimes with a little oil meal. is the grain mixtule

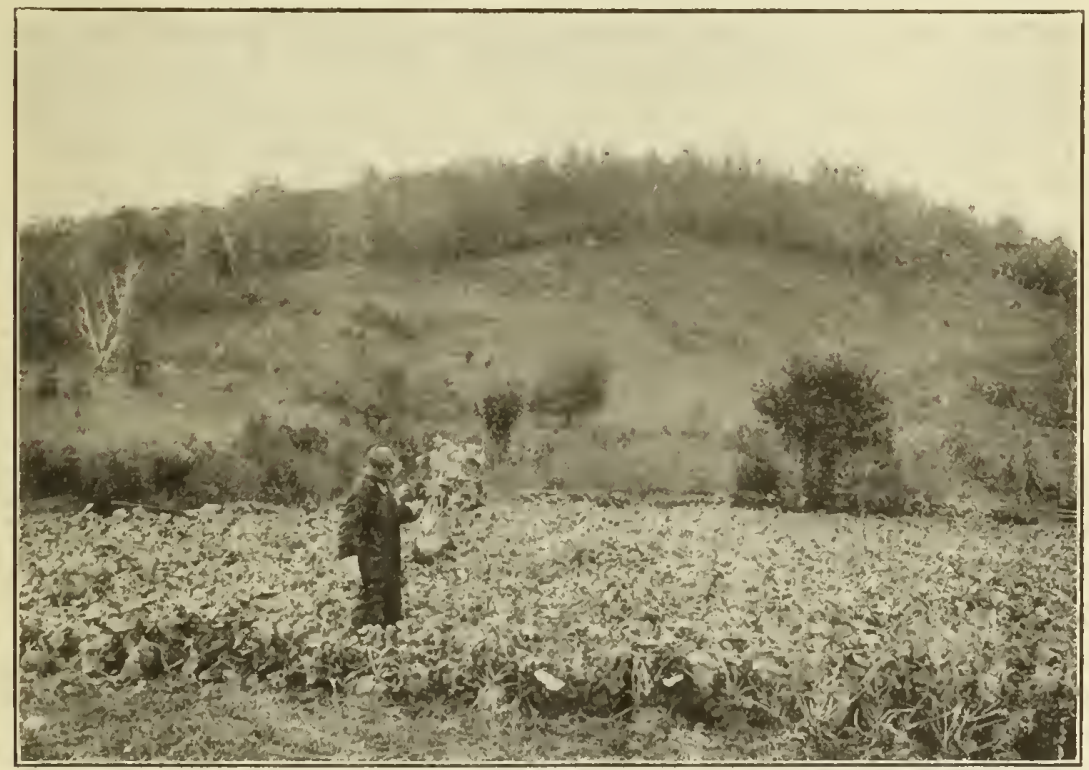

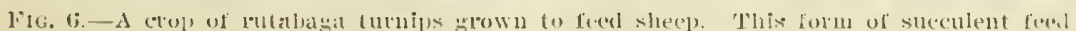
should be mote generaily used is a part of the regular witutio ralton for sleep. The topography and regetation of the pasture in the background is typical of much New England lanki. 
most commonly nsed. The amomt of grain needed seems to depend mnch mpon the other feeds arailable and to some extent npon the season. If plenty of the finer varieties of hay, partienlarly clover, las been used, together with succulent feeds in the form of roots $01^{\circ}$ silage, lont little grain is needed. On the other hand, if the roughage has consisted largely of coarse, inferior hav, and little $O \mathrm{r}^{\circ}$ no sncenlent feed, grain needs to be fed in much larger quantities and for a mnch longer period. As a general thing it will not pay to keep sheep muless the liays cited as best adapted to their needs can be grown together with some form of sneculent feerl. Some growers feed no grain at all, but the better ones make a practice of graining for a time, from 4 to 6 weeks in the spring of the year before turning ont to pasture, and without dombt it is feed well worth while. The principal thing is to keep the flock in good condition at all seasons of the year, and in order to do this some grain is nsmally essential for at least a month in the spring of the year. especially if the lambs come before the ewes go on grass.

\section{FRESH AIR AND EXERCISE.}

It is known that these two factors of care, which lave so direct an effret upon the health of sheep, are too often ignored, and their importance can not be oreremplasized. Elaborate and expensive ventilating derices or buildings ${ }^{1}$ are not necessary, the main prin(iple to be observed in making provision for ventilation being to make slle tlat flesh arir is to be had at all times withont exposing the flock to drafts. 'The pens should be roomy, at all times rly, and the sheep should he allowed a chance to get ont of doors during the day. If necessary to indnce exercise, a part of the feed can lie scattered ont of doors on the snow. but at no time shonld sheep be exprosed to driving snow storms or drenching lains.

\section{ATTENTION IN THE SPRING.}

Sheep requile relatively little time as compared with other kinds of stock, but attention at certain times is important. At lambing time sheep require close attention, the importance of which is well expressed in Farmers' Bulletin 810, page 14, in the following statement: "The lambing season is the shepherd's harvest time, and the -ize and quality of the crop practically determine the profits * * *. It this time extra attentiou must be given to the erres and lambs. In no other way can time be used to better adrantage on the farm." The sort of attention necessary at this season is fully discussed in the

${ }^{1}$ Equipment and bulding construction for farm sluep raisinz are fully dlscussed in Firmers IBulletln 810 , which ls obtainable from the Department of Agriculture upon request. 
bulletin referred to, while the respective advantages of early and late lambing will be discussed later.

Dipping the sheep, docking and castrating the lambs, etc., are also fully discussed in Farmers' Bulletin 8t0, pages 14 to 18 . Regularity of practice in these regards is an essential factor bearing upon success $\pi$ ith sheep.

\section{ADVERSE FACTORS.}

DISEASES.

Of the difficulties encountered in sheep raising in New England it is beliered that the disease factor is the most important. While but little disease occurred during the year the study was made, taking the sheep-raising sections of New England as a whole. year in and year ant, it is known that much loss results through disease. Some growers have but little trouble in this respect, especially those who are careful about selection. feed well, proride sanitary quarters, and keep their flocks in the prime of condition throughout the season. while others report large losses, at times as high as 50 per cent of their entire flocks. (Several such instances were reported during the spring of 191\%.)

It is not the purpose of this bulletin to tell how to treat the various diseases to which sheep are subject. but attention is called to those which have most frequently to be contended with, and anyone keeping sheep is adrised to acquaint himself with the symptoms and treatment of each. It is believed that much loss can thus be averted.

Stomach rorms, ${ }^{1}$ grub in the head, nodular disease of the intestines. and indigestion are the troubles most frequently reported in New England and seem to be the ones to which most loss is due. Skin diseases and ticks ${ }^{2}$ are also important and give consideralle trouble unless regular dipping is practiced.

Much complaint is heard of flocks l'mning out or degenerating, and many breeders say that they have to sell out and start their flocks anew at intervals of every 8 or 10 years. It is beliered that a great deal of the running out of flocks is due as much to worm trouble, which is not recognized as such in many cases, as to anything else. $\perp$ change of pasture at interrals of every 10 dars $0 \mathrm{r}^{\circ}$ two weeks is recommenderl as a safeguard against norm trouble, though this is not always practicable as New England pastures are located. It is likely that much more could be done in combating this disease by making more extensive use of afternaths and forage crops

\footnotetext{
${ }^{1}$ Farmers' Bulletin 84n, p. 20; also Burean of Animal Industry circular (Zoological Ibision, entitled "llow to prepare and administer the bluestone or copper sulphate dosage in the treatment for stomach worms."

2 "Sheep scab" is fully discussed in Farmers' Bulletin 613 and the "Sheep tick" in Farmers' Bulletin $\mathbf{7 9 8}$, eitler of which is obtainable upon request from the lepartment of Agriculture.
} 
in supplementing the regular pastures. Is prevention of infection is the most practical means of handling this tronble, it is important that the breeder inform himedf of the method outlined in Farmers' Bulletin $810 \mathrm{in}$ order to be better enabled to cope with it.

$\Delta$ few growers. who alrearly have regular pastures so located as to permit shifting. recognize the advantages of changing pasture and make a practice of changing their flocks from one pasture to another, and sometimes to a third, during the same season, and thongh in inost cases they ean give no good reason for their success, they claim to get better results by so loing. Since the length of time on each pasture is much greater than two weeks (the maximum time a pasture can be oecupied and insure safety from infection). it is likely that the advantage gained in this respect is due to the better feed afforded rather than to the prevention of worms, yet the practice is a good ane and shonld be more generally followed.

The appearance of some flocks bronght under the writer's observation, and their histories as told by the owners, lead to the conclusion that most of the so-called ruming ont not due to discase can be attributed to poor care and to degeneration as a result of long-continned inbrecting. Inbreeding to any great extent should be aroided and new blood introduced occusionally in order to maintain vigor and vitality.

The disease factor is one which can hardly be oreremphasized. It appears to be one of the most important factors, probably much more so at present than the dog question, in the development and profitableness of the sheep influstry of New England.

THE DOG QUESTION.

What has many times been set forth as one of the greatest obstacles to sheep raising in New England is the log. Loss from canine depredation is considerable. and it is sometimes claimed that the $\log ^{1}$ was responsible for the lecline in sheep raising in the eastern portions of the conntry. From the figures heretofore given, showing the profits under former prices, together with investigation in respect to this particular question, it would appear that other factors, particularly discase. low prices. and the development of cheaper grazing lands in the West, were each quite as potent as the dog in this regard.

It must not be inferred from this that the dog question is to be ignored. It is still a serious one, and one that calls for further remedial legislation, in some states at least. There is. however, a marked improvement in public sentiment and good prospect that sheep growers will get additional protection in this regarl.

${ }_{1}$ Th. guestion of the sherp-killing dog is fully discussed ln l'armers' Bulletin 935, which is obtainable from the Department of .Ifriculture upon request. 
Wild animals, particularly bears, are said to be quite as great a menace as the $\operatorname{dog}$ in some of the more remote regions, but such conditions are rare.

\section{SIZE OF FLOCK.}

Since in New England, with but few exceptions, sheep are kept in small flocks ${ }^{1}$ only, the question naturally arises: Are sheep so kept because large flocks are unprofitable? Practically all the farmers interviewed agreed that sheep do better in small flocks, and while some could gire no good reason for their belief, others were of the opinion that the better results obtained from sinall flocks were due to the better care received by each individual. The same principle as regards the strong and weak applies with sheep as with other animals, and it is a great mistake to put weak, immature sheep or old ewes in with a lot of strong inclividuals and expect all to do well.

Probably one reason why large flocks hare not done better in England lies in the limited housing space a vailable on the arerage farm. Most farms on which cattle are kejt have housing space for a small flock only, and all growers agree that sheep shonld not be crowded. Not only is the wool clipped per head likely to be less when the sheep are kept in crowded quarters, but also the chance for clisease, ticks, and improper nomrishment is greatly increased. Sheep need, in addition to wholesome feed, plenty of room, a chance to exercise, and good rentilation, none of which can be had in crowded quarters. Some farmers keeping no more than 40 ewes separated them into two flocks, dnring both summer and winter, saying that they obtained better results by so doing. It may be that in these cases lousing space was so arranged as to accommodate only 20 head in one flock, but in the light of the experience of others. it is believed that as many as 40 sheep. and probably a few more, can be safely handled in one flock, providerl all are good strong individnals, housing space is adequate, and fred and pasturage plentiful.

Farmers' Bulletin 840 points ont that at least 30 ewes, or. better still. 60 or more. can be much more economically handled than a very small flock, and that because of its being a nuch more important part of the farm business the large flock is likely to receive more attention and better care than the very small one.

In a few instances large flocks of sheep are being kept in New England with good success. but these cases are the exception l'ather than the rule, and ocenl where practically the entire business of the farm is caring for sheep. One of the largest breeder's in New Hampshire keeps on an arerage from 2.5 to 2.50 breeling ewes, keeping them both summer and winter in three separate flocks. Where close

\footnotetext{
"In this discussion the term "small flock" inclurles mmbers un to 40 or 50 head.
} 
attention can be given, such as these flocks receive, results from large flocks are sat isfactory, but such flocks are not to be recommented for the general farmer. who has not the time to derote to giving them the close attention required.

IThile it is no doubt possible. under (ertain conditions, especially at present prices, to make sheep in large flocks pay. it is more than likely that the small flock-consisting of from 20 to 50 head, depending upon housing space and available summer pasture-kept in conjunction with dairy cattle as a general farm proposition, is the most desirable flock for New England. The figures given show that, with but few exceptions, sheep are kept in practically no other way: the experiences of growers lead to the same conclusion, and farmers themselves are of the same opinion.

\section{QUESTIONS OF BREEDS AND BREEDING.}

Sheep of the middle-wooled "down" breeds are the most numerous in New England. and of these the Shropshire and Iampshire are probably the most common. Dorsets and Cheriots are important in some regions, and other breeds to a less extent. Traces of Merino blood are also to be found in some flocks, especislly among the older flocks. whose owners were in the business when the production of wool was the main reason for keeping sheep. Most of the flocks are "grades;" the better breeders keeping pure-bred rams and grading u1) their flocks to some particular breed, while in a few flocks. whose owners say they keep "just sheep," it is difficult to detect the marks of any particular breed.

As to the comparative merits of the different breeds ${ }^{1}$ there is great diversity of opinion. All agree that the "down" breeds are more easily handled in regard to fencing. but it is claimed that some of these breeds are less hardy and fo not withstand the rigorous New England climate as well as some other breeds. Any number of instances are known, howerer. where the breeds condemned for this reason are being kept with good success, so that something other than the breed is evidently at fault with those who claim poor success. The Cheriots, on the other hand, are noted for their harliness. and somo prefer to cross in with the Cheviots in order to secure this hardiness. While the same adrantage is claimed for the Merinos by those who still have that blood. Dorset crosses are kept where early lambing qualities are desired.

For a general farm proposition New England needs a dual-purpose sheep that will produce a good heary lamb in a reasonably short time and grow a good flece of wool in addition. The middle-wooled

1 Fully discussed in Farmers sulletin 576 , to be obtained from the Department of Agriculture upon request. 
mutton breeds seem to come the nearest to fulfilling these requirements, and it is known that these breeds do well if careful selection of breeding stock is practiced and good care given at all times. Within this class it is a matter of choosing one s farorite breed, picking out good strong ewes each year and occasionally introducing new blood, preferably of the same breed. Crosses do well in some instances, but the promiscuons mixing of breeds is in nowise to be recommended, and under usual circumstances it is the best practice to stick to the same breed. aiming at all times to keep none but strong, healthy stock.

\section{EARLY VERSUS LATE LAMBS.}

As to the best time to have lambs come, whether early or late spring, there is great diversity of opinion, and numerous growers can be found who are following each method, apparently with equally good results. Either method has its advantages and disadrantages, and which practice one should follow depends to a large extent upon market demands and the facilities of individual breeders for handling sheep. Early lambs are said to be less subject to attacks of parasites ${ }^{1}$ than are late lambs, which is a very important factor where stomach worms have given trouble. It is claimed by those who have their lambs come early that by getting an earlier start they make larger lambs, which can be turned off earlier than when they come later. It is also pointed out that early lambing permits of dipping, docking, and castrating before the lambs are tnrned a way to pasture, important operations which are likely to go undone if the lambs do not come until the ewes have gone on grass.

Those who have their lanibs come late claim, on the other hand, a great saving in expense for grain, the lambs requiring no grain and the ewes but little as compared with that fed to both for a long period under the other method. With this method it is said that scarcely any trouble is experienced with ewes not having milk and disowning their lambs, a trouble which occurs to a considerable extent where lambs are dropped early. Also with late lambs less attention is required at lambing time, and it is claimed that if pastures are good and the season not cold the lambs begin to grow at once and make a much better and quicker growth than where the lambs come earlier.

From the writer's observations, while late-dropped lambs may make a quicker growth, in regions where this method is practiced lambs are not marketed until a month or so later than in other regions, and where the market demands summer and early fall lambs, it is doubtful if late lambs will make a profitable growtl. 
While miny young awes are bed to lamb at yearling age, the advisability of the practice as a geneal one is questionable. Many breaders are of the opinion that the growth of the areage ewe lanb is greatly impaired if she is bred to lamb at yearling age, and that, while many young ewes can be bred to lamb at that age, small stock will result if this practice is followerl. Others, howerer, say that if their lants lave been born early in the spring and have marle good growth, the ewe cam be bred to lamb at one year of age with no evil results. 'The writer knows of a few breeler's who take exceptionally good care of their flocks and raise strong early lambs, and who are following this practice with apparently goor success. It is likely, howerer. that the practice is not, to be recommended for the average grower, whose lambs are born none too early in the spring to make the growth escential, and that an increased lanbing rate can better be achieverl by other means.

SINGLE VERSUS TWIN LAMBS.

In the precerling pages it has been shown that in order to increase the lambing rate to 100 per cent on the farms studied about onefourth of the breeding ewes munt raise twin lambs. Many growers prefer to have their ewes raise but one lamb, saying, in most cases, that "one good lamb is better than two poor ones," but here again it seems a matter of care more than anything else, and the best breeder's see no objection to a good strong ewe raising a pair of lambs, nor do they think that twiu lambs are likely to be much smaller than those dropped singly. They prefer, in most cases, to have young ewes and old ewes raise but one lamb each, but do not object to strong medium-aged ewes having more than ome lamb. The mole successful growers aim to get as many lambs as possible. and one of the best ways of increasing the lambing rate seems to be hy selecting aleng this line.

\section{SHEFP ON LARGE RANGES.}

The writer's attention las been callerl to a couple of large ranges; one, embracing upwairl of 4,000 acres, a large part of which affords fair grazing. being citerl as a possibility for a large sheep proposition; the other, which was said to earry 500 or 600 sheep, as a striking c xample of failure dlue, as nearly as could be retermined, to diseasa and lack of cale. One drawback to the first proposition, and without dloubt to otlers of its sort. was its lack of tillable land, or at least enough of such laud on which to grow the uecessary forage for wintering the breeding stock. This difficulty could perhaps be obviated by operatiug the range in conjumtion with tillable farm land in the same of other localities, utilizing the range as pasture 
during the summer and housing the breeding stock during the winter on the farms growing the forage. Such a proposition should be carefully considered from all angles, however, before making the venture, and especially in reference to suitable feeds and trouble from disease. These two factors are of vital importance with the small flock, but their importance is magnified many fold when it comes to keeping sheep in large numbers. The small farm flock can be handled in connection with other stock with but little trouble, and, if well cared for, under present prices at least, it is a valuable asset to its owner. The large flock, on the other hand, calls for close attention, and requires the services of a shepherd who thoroughly understands his business if success is to be expected. 


\title{
PUBLICATIONS OF THE U. S. DEPARTMENT OF AGRICULTURE RELATING TO SHEEP RAISING.
}

\author{
PUBLICATIONS AVAILABLE; FOR FREE DISTRIBUTION BY THE DEPARTMENT OF \\ AGRICULTURE.
}

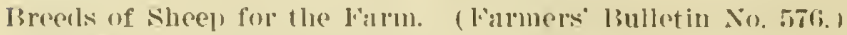

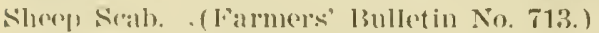

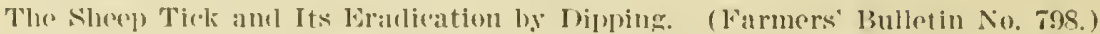

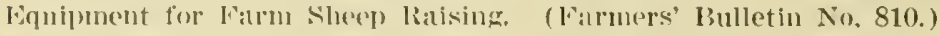

Fann Shoep latisiug for l3oginners. (Falmers' bulletin No. 840.)

'The slleep Killing I)og. (Farmers' Bulletin No. 9:35.)

'Tho Woolgromer ambl the Wool Trale. (Department Bulletin No. 206.)

Tho Chemical ('omposition of Lime-sulphur Animal Dips. (Department Bulle(in No. 4.51.)

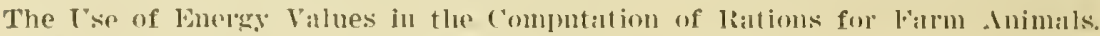
(1)eparturent l3ulletin No, 459.)

Sugecetions foom . Iustralasia to American Sleep Ratisers. (Separato (;4. from lear Iook 1914.)

liarakul Sheep. (Separate 673 from Your l3ook 1915.)

PUBLICATIONS FOR SALE BY THE SUPERINTENDENT OF DOCUMENTS, GOVERNMENT PRINTING OFFICE, WASHINGTON, D. C.

Slleep Killing Dow. (Farmers' Bulletin No. 65̃2) Price, 5 cents.

Management of Sheep on the Farm. (Department Bulletin No. 20.) I'rice. 10 rents.

Domestic Broerls of American Sheep. (Department Bulletin No. 94.) Price, 25 rents.

Features of the Sheep Industries of the Enited States. Now Zealamd, and Australia. Comparel. (Department Bulletin No. 313.) Price, 10 cents.

Experiments in Vaccination Ag:linst Anthrax. (Department Rulletin No. 340.) Price, it conts.

Larkspur l'oisoning of Live Stock. (Department Bulletin No. 365.) Price, 25 cents.

Grazing Industry of the Blue-Grass Region. (Department Bulletin No. 397.) Price, 5 cents.

Sheep Scab, Its Nature and Treatment. (Bureau of Animal Industry Bulletin No. 21.) Price, 15 cents.

Prevention of Isosses Among sheep from Stounach Worms, Haemonchus Contortus. (Bureau Animal Industry Circular No. 157.) Price, 5 cents.

Pasturage Systen for Handling Iange Sheep. Investigations luring 1909. (Forestry Circular No. 178.) Price, 5 cents.

Sperial leport on History inu Present Conditions of sheep Industry. (Bureau of Animal Industry.) Price, $\$ 1.40$. 


